\title{
Helen Salisbury: Reasons to be fearful
}

\author{
Helen Salisbury GP
}

Oxford

Most doctors take their work home with them-literally, in the shape of emails to write and results to check, or figuratively, in their heads. We worry about patients at risk and whether we've taken the right decisions. It's often exhausting, disrupting our sleep or intruding into our time off, when we should be attending to friends or family.

How do we develop the confidence that we're good enough doctors? We've been adequately trained, we've passed our exams, and we make the best decision we can with the available evidence. We know that continuing to worry once we've closed the surgery door can be a recipe for burnout.

So, how can we learn to let go? Experience helps: the longer you practise without major error, the more the fear recedes, but for some doctors it never goes away.

Is the solution to improve our personal resilience-learn to relax and not be prey to anxiety? Would we all be better off after a few sessions of cognitive behavioural therapy and mindfulness? Some evidence shows that mindfulness training may reduce symptoms of burnout, ${ }^{1}$ but many doctors are sceptical that it's an adequate answer. ${ }^{2-4}$

Under ideal conditions we may have confidence in our training and our decision making, but what if we're in a rush? You know that you should have done a risk assessment for the patient with diabetes, hypertension, osteoarthritis, and low mood, but you had a 10 minute appointment and a full waiting room. Would a more thorough examination of the patient with sciatica have been a better use of time than listening to the problems he has with painkillers and his struggle to keep his job? These are the consultations we revisit, questioning whether we prioritised things correctly, hoping that we didn't miss anything dangerous, and wondering if we did a good enough, safe enough, job.
When we eventually leave work we hand over to out-of-hours GPs, district nurses, and emergency departments. For peace of mind I need to be confident that a responsive service will be ready to spring into action if my patients do run into problems. Knowing that our emergency services are stretched to breaking point and sometimes beyond, it's getting harder to keep this faith that others will be able to pick up the pieces.

Above all, we need confidence that we'll be supported if things go wrong. While doing our best with the information and resources available, we need to know that colleagues and professional bodies will support us. After the General Medical Council's handling of the Bawa-Garba case, ${ }^{5}$ many doctors don't have such confidence.

Although I enjoy my job and find many reasons to be cheerful, there are also reasons to be fearful.

Competing interests: See www.bmj.com/about-bmj/freelance-contributors.

Provenance and peer review: Commissioned; not externally peer reviewed.

1 Verweij H, Waumans RC, Smeijers D, etal . Mindfulness-based stress reduction for GPs: results of a controlled mixed methods pilot study in Dutch primary care. Br J Gen Pract 2016;66:e99-105. . 10.3399/bjgp16X683497 26823271

2 Cheshire A, Ridge D, Hughes J, etal . Influences on GP coping and resilience: a qualitative study in primary care. Br J Gen Pract 2017;67:e428-36. 0.3399/bjgp17X690893 28483822

3 Ripullone K, Womersley K. What we don't talk about when we talk about professionalism: resilience. 14 Mar 2019. https://blogs.bmj.com/bmj/2019/03/14/what-we-dont-talk-aboutwhen-we-talk-about-professionalism-resilience/.

4 Gerada C. Clare Gerada: Mindfulness is useful but not the only option. BMJ 2019:367:15698. 10.1136/bmj.15698 31575529

5 Nagpaul C. The Bawa-Garba ruling: our response. BMA. 30 Jan 2018. https://www.bma. org.uk/connecting-doctors/b/the-bma-blog/posts/bawa-garba-ruling-our-response.

Published by the BMJ Publishing Group Limited. For permission to use (where not already granted under a licence) please go to http://group.bmj.com/group/rights-licensing/ permissions 